\title{
An unusually elongate endogeic centipede from Sardinia (Chilopoda: Geophilidae)
}

\author{
Lucio BONATO ${ }^{1, *}$, Marzio ZAPPAROLI ${ }^{2}$, Leandro DRAGO ${ }^{3}$ \& Alessandro MINELLI ${ }^{4}$ \\ ${ }^{1,3,4}$ Dipartimento di Biologia, Università di Padova, via Ugo Bassi 58B, I-35131 Padova, Italy. \\ ${ }^{2}$ Dipartimento per la Innovazione nei sistemi Biologici, Agroalimentari e Forestali (DIBAF), \\ Università della Tuscia, via S. Camillo de Lellis s.n.c., I-01100 Viterbo, Italy. \\ *Corresponding author: lucio.bonato@unipd.it \\ ${ }^{2}$ E-mail: zapparol@unitus.it \\ ${ }^{3}$ E-mail: leandro.drago1@gmail.com \\ ${ }^{4}$ E-mail: alessandro.minelli@unipd.it \\ ${ }^{1}$ urn:lsid:zoobank.org:author:DEFC50E9-439C-45A1-8EFE-EFFE745D391F \\ ${ }^{2}$ urn:lsid:zoobank.org:author:30E6BE85-C1DA-4215-A07D-652C9770AEC9 \\ ${ }^{3}$ urn:lsid:zoobank.org:author:84133787-C29F-496D-B3D5-1E4372093FD4 \\ ${ }^{4}$ urn:Isid:zoobank.org:author:D9FA639F-7538-441C-9572-032FD6C4EEDE
}

\begin{abstract}
Endogeophilus ichnusae gen. et sp. nov. (Chilopoda: Geophilidae sensu stricto) is described based on three specimens from two localities in south-western Sardinia, examined by light and scanning electron microscopy. The new centipede resembles the rare Ibero-Pyrenean genus Galliophilus Ribaut \& Brolemann, 1927 in some features, especially in the forcipular segment, and the temperate European species Geophilus electricus (Linnaeus, 1758) in other features, especially in the ultimate leg-bearing segment. However, the true affinities of E. ichnusae gen. et sp. nov. are uncertain, because the new species departs significantly from the majority of geophilids for the higher number of legs (91-107 pairs in the specimens examined), the slender trunk segments (the sternites being longer than wide), the relatively stout legs (the tarsus being only about twice as long as wide) and the very short setae $(\leq 15 \mu \mathrm{m})$ scattered on the body surface. All these features are probably derived and suggest adaptation to a more strictly endogeic habit than other geophilids.
\end{abstract}

Key words. Geophilidae, morphology, taxonomy, Sardinia, endogeic.

Bonato L., Zapparoli M., Drago L. \& Minelli A. 2016. An unusually elongate endogeic centipede from Sardinia (Chilopoda: Geophilidae). European Journal of Taxonomy 231: 1-19. http://dx.doi.org/10.5852/ejt.2016.231

\section{Introduction}

Sardinia is a large Mediterranean island, hosting a high number of soil-dwelling arthropod taxa. A significant portion of the pedofauna is exclusive of the island, or of the Corsica-Sardinia complex, and many of these endemic species are deeply divergent from the closest relatives from other areas (e.g., AA.VV. 1983). The exploration of the island and the description of its soil fauna are still ongoing, and 
recent samplings and investigations are adding significantly to its knowledge (e.g., Cerretti et al. 2009; Nardi et al. 2011).

Centipedes (Chilopoda) are well represented in the Sardinian soil communities and have been broadly surveyed in the past (Minelli 1983; Zapparoli 2009, 2011). Recently, however, an unprecedented sampling effort dedicated to the endogeic fauna in south-western Sardinia has provided a small sample of specimens of an undescribed geophilid centipede, which is remarkably unusual in many respects (Zapparoli 2009, 2011). The new species is here described and illustrated by means of light and scanning electronic microscopy, it is compared with other geophilids and its unique morphological features are tentatively interpreted in terms of ecological adaptation to the endogeic environment.

\section{Material and methods}

Specimens were collected by Luca Fancello while sampling endogeic beetles with the following technique (Fancello et al. 2009; Zapparoli 2011): soil was extracted up to a maximum depth of about $50 \mathrm{~cm}$, the superficial humus layer was removed when present, and detritus was sorted in Berlese-type funnels modified according to Pace (1996).

Specimens were fixed in 70\% ethanol and examined by a Leica DMLB microscope after inclusion in ethylene glycol in temporary mounts, following standard protocols for geophilomorph centipedes (Pereira 2000). Measures were taken by means of a micrometre eyepiece. Digital photographs were taken using a Leica DFC420 camera applied to the microscope and assembled using the image stacking software CombineZP (Hadley 2008). Line-drawings were produced manually from the photographs.

Scanning electron microscopy was applied to selected body parts of a single specimen, after dehydration through a graded ethanol series $(80 \%, 95 \%, 100 \%$, at least 1 hour each step), critical-point drying with $\mathrm{CO}_{2}$ and coating with gold. Sonication was avoided to prevent loss of setae. The samples were examined with a Cambridge Stereoscan 260 microscope.

The holotype of the new species was compared directly to specimens of another 20 species selected from different genera of Geophilidae. To control for possible sexual differences, only adult females were selected. The following measures were taken: head width and length of the longest seta on the cephalic plate; length and width of a metasternite and of a leg tarsus at about $20 \%$ of the total series of leg-bearing segments. All measures were taken by one person (L.B.) using the same microscope. Specimens examined: Abatorus allredi Chamberlin, 1965, California, UCRC06; Acanthogeophilus spiniger Meinert, 1870, Morocco, PD5153; Arenophilus peregrinus Jones, 1989, Great Britain, PD5754; Chomatophilus sp. Pocock, 1896, Mexico, UNAM003; Clinopodes flavidus C.L. Koch, 1847, Italy, PD1269; Diphyonyx conjungens (Verhoeff, 1898), Turkey, PD1144; Eurygeophilus pinguis (Brölemann, 1898), Italy, PD4254; Galliophilus beatensis Ribaut \& Brolemann, 1927, France (no direct examination, but data from Brolemann 1927); Geophilus alpinus Meinert, 1870, Italy, PD680; G. carpophagus Leach, 1815, Canary Islands, PD2058; G. electricus (Linnaeus, 1758), Italy, PD569; G. fucorum Brölemann, 1909, Italy, PD3156; G. piae Minelli, 1983, Italy, PD3148; G. pygmaeus Latzel, 1880, Italy, PD638; G. richardi Brölemann, 1904, Italy, PD5776; G. truncorum Bergsøe \& Meinert, 1866, Great Britain, PD943; Pleurogeophilus mediterraneus (Meinert, 1870), Italy, PD1154; Sogona sp. Chamberlin, 1912, Mexico, PD1382; Stenotaenia sorrentina (Attems, 1903), Italy, PD5758; Tuoba poseidonis (Verhoeff, 1901), Malta, PD947.

For the morphological terminology, we followed Bonato et al. (2010).

For the collections, we used the following abbreviations: 


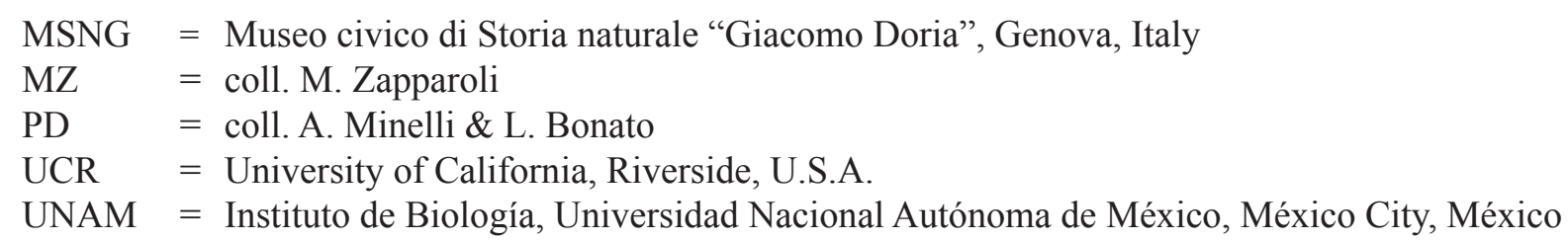

\title{
Results
}

\author{
Class Chilopoda Latreille, 1817 \\ Order Geophilomorpha Pocock, 1896 \\ Family Geophilidae Leach, 1815 \\ Endogeophilus gen. nov. \\ urn:lsid:zoobank.org:act:0904F67C-219A-459F-A121-3D0C7E47D469
}

Figs 1-4; Table 1

\section{Type species}

Endogeophilus ichnusae gen. et sp. nov.

\section{Diagnosis}

Geophilids with body almost uniform in width, only slightly tapering at both ends; head slightly longer than wide; clypeus uniformly areolate, without clypeal areas; intermediate part of the labrum bearing a few tubercles; labral side-parts distinct from the clypeus, well separated from each other, their posterior margin with bristles; first maxillae with bi-articulated telopodites and two pairs of short lappets; second maxillary coxosternite with long isthmus, without inner processes, and lacking distinctly sclerotized ridges; second maxillary telopodites composed of three articles, bearing a simple, sub-conic claw; forcipular tergite sub-trapezoid, posteriorly about as wide as the subsequent tergite, the lateral margins distinctly converging anteriorly; forcipular coxosternite slightly wider than long, without anterior denticles, chitin-lines complete, coxopleural sutures complete and distinctly diverging anteriorly; forcipules stout and strongly tapering, with two distinct intermediate articles: forcipular tarsungula abruptly narrowing, relatively short and only weakly curved, with a single small basal denticle; carpophagus pits shallow; leg-bearing segments with a sub-ovoid/sub-triangular pore-field on the posterior half of each metasternite; leg claws bearing two slender accessory spines; ultimate legbearing segment with pleuropretergite entire, metasternite sub-trapezoid wider than long; coxal pores mainly opening along the ventro-internal, anterior and dorso-internal sides of the coxopleuron, with an additional isolated ventral pore; telopodites of the ultimate leg pair composed of six articles, slightly swollen in the male in comparison with the female, bearing a claw; bi-articulated gonopods in the male, short gonopodal lamina in the female; a pair of anal pores.

Differential characters with respect to the most similar genera are given in Table 1.

\section{Etymology}

Composed of the prefix "endo-", from the classic Greek $\varepsilon v \delta o v$ (inside), and the genus name Geophilus, which is from the classic Greek prefix $\gamma \varepsilon \omega$ - (earth) and $\varphi \imath \lambda \varepsilon \dot{\omega} \omega$ (to love), referring to the endogeic habitat. The gender of the genus name is masculine. 
巳 $\vec{z}$ 웅

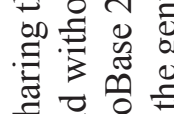

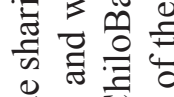

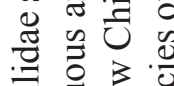

言刍完 융워 范

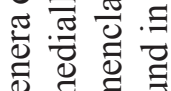

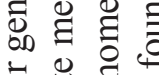
$\dot{\mathrm{s}} . \stackrel{0}{9}$ 흉 节芯. 击 घี ญ 完离 를 ฮี่ ऽ चี की : 0 $\infty 000$ $\therefore$ ह $\frac{2}{2}$ 뇌류 . 壳 0000

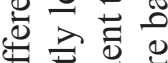

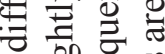
की

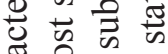
형 离 ठ त त

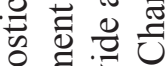
क्⿹

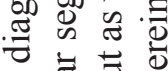

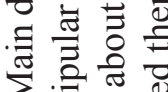
$\sum \sqrt{0} \pi$ कि क्ष 施 诺 盯 Ð 㐘 00

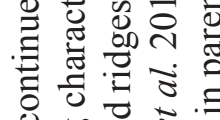
过

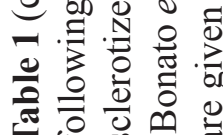

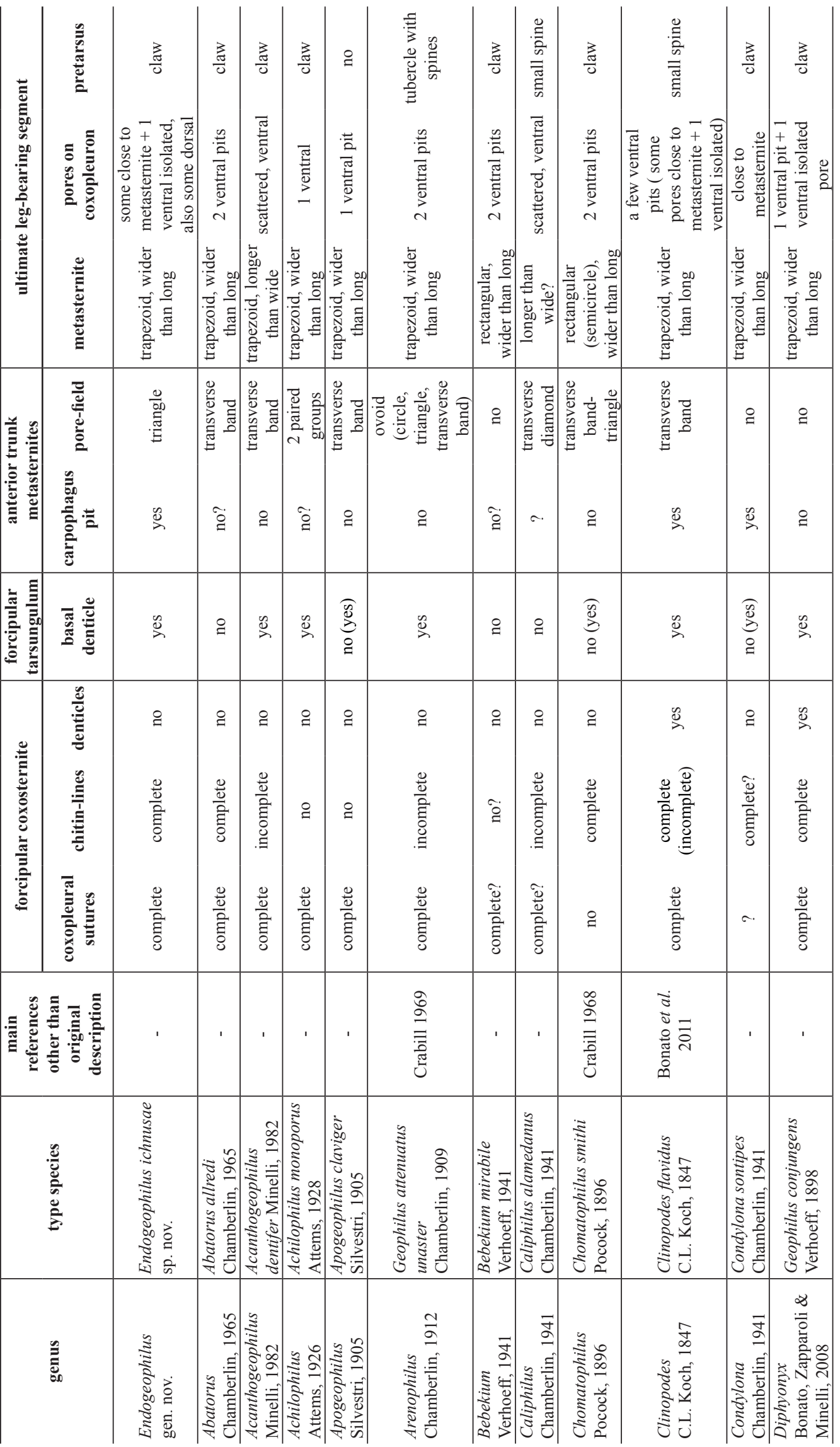




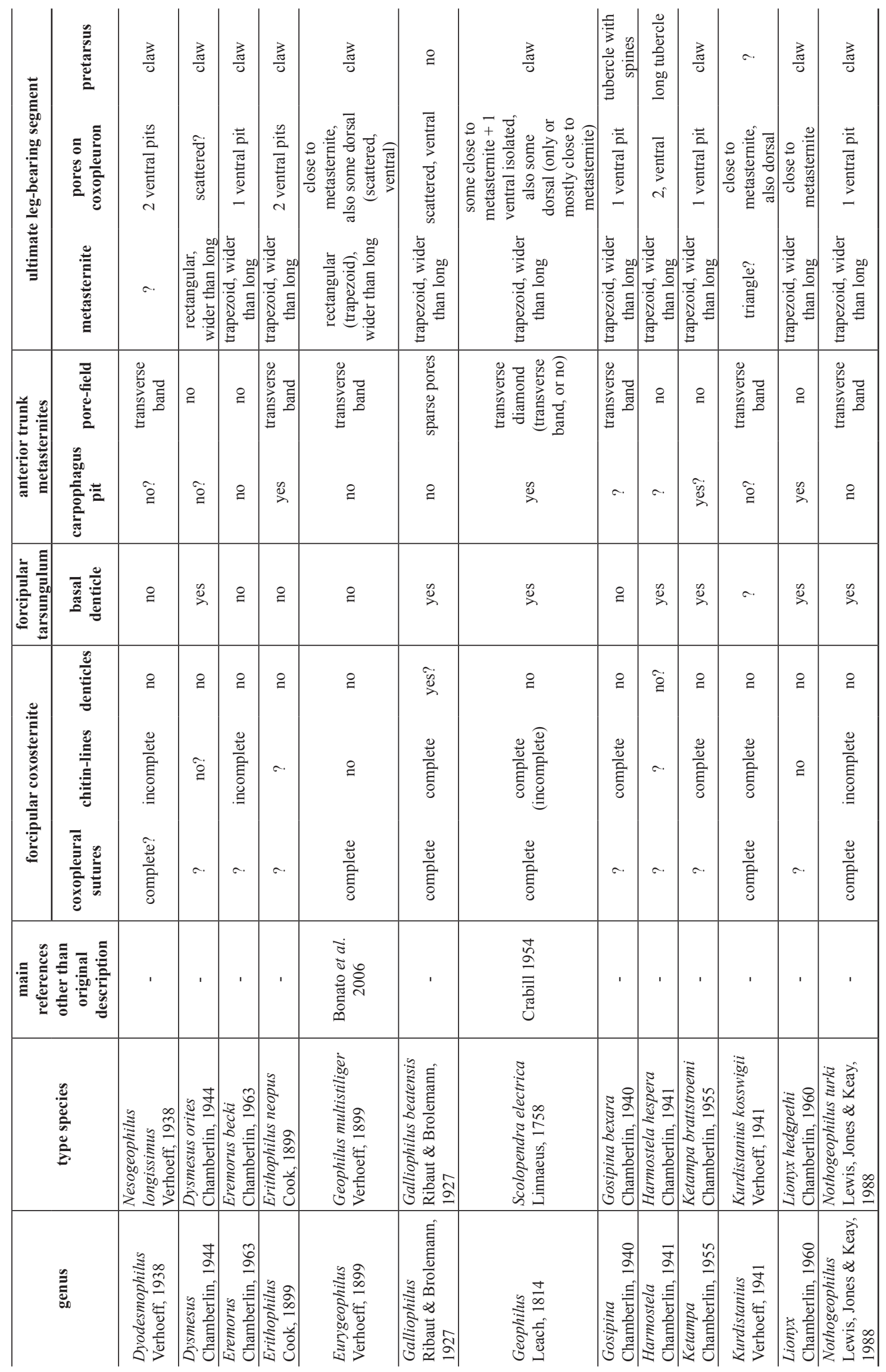




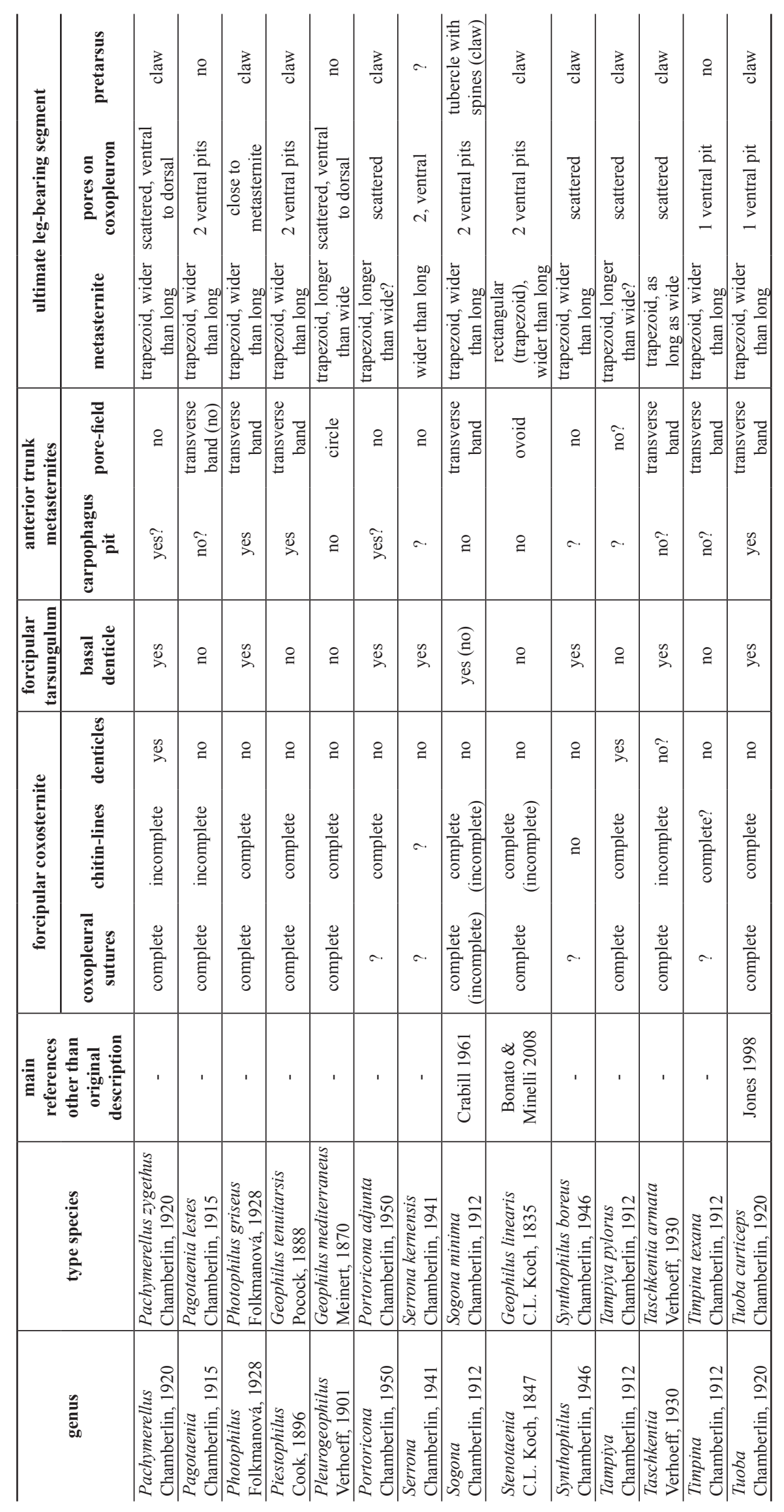


Endogeophilus ichnusae gen. et sp. nov. urn:Isid:zoobank.org:act:BF3DE3C0-542A-4767-A62E-6C9D6A2923AD

Figs 1-4

Geophilidae sp. nov.- Zapparoli 2009: 145, 155.

Geophilidae n. sp.-Zapparoli 2011: 240.

\section{Diagnosis}

As for the genus (see above).

\section{Etymology}

From the Latin Ichnusa, which is from the Greek I $\chi v o v \sigma \sigma \alpha$, ancient name of Sardinia. The species epithet is a noun in the genitive case.

\section{Type material}

Holotype

SARDINIA: adult,$+ 34 \mathrm{~mm}$ long, with 107 leg-bearing segments, Colle di Campanasissa, between Siliqua (Province of Cagliari) and Nuxis (Province of Carbonia-Iglesias), 280 m; 27 Dec. 2006, L. Fancello leg., in ethanol, head detached from trunk (MSNG, code 58344).

\section{Paratype A}

SARDINIA: adult $\widehat{\partial}, 32 \mathrm{~mm}$ long, with 95 leg-bearing segments, same site and date of the holotype, in ethanol, head detached from trunk, some pieces of trunk gold-coated for SEM examination (MZ).

\section{Paratype B}

SARDINIA: adult $\widehat{\partial}, 31 \mathrm{~mm}$ long, with 91 leg-bearing segments, Mamenga, Marganai forest, near Domusnovas (Province of Carbonia-Iglesias), 610 m, 1 Mar. 2006, L. Fancello leg., in ethanol, not dissected (PD, code 1373).

\section{Description}

\section{Female}

Description of holotype (see also Figs 1A-F, 2, 4)

General FEATURES. Body remarkably narrow, $34 \mathrm{~mm}$ long, uniformly $0.5 \mathrm{~mm}$ wide for most part of the trunk, only slightly narrowing anteriorly along ca 30 most anterior leg-bearing segments and backwards along ca five most posterior leg-bearing segments, both the first and the ultimate leg-bearing segments being $0.4 \mathrm{~mm}$ wide. Legs relatively short, most of them uniformly $0.4 \mathrm{~mm}$ long, a few tens of most anterior pairs decreasing gradually, the legs of the first pair being $0.3 \mathrm{~mm}$ long. Colour (in ethanol) almost uniformly pale yellow, only the forcipular condyles and the distal part of the tarsungula distinctly darker.

Cephalic Capsule. Cephalic plate sub-rectangular, 1.2 times as long as wide, 0.9 times as wide as the forcipular tergite, the anterior margin slightly angulated with a medial notch, the lateral margins slightly convex, the posterior margin straight; transverse suture absent; setae rare and short, up to ca $15 \mu \mathrm{m}$ long. Clypeus uniformly areolate, without clypeal areas and without plagulae; lateral margins complete; a total of 6 setae, arranged in a longitudinal series of three pairs on the anterior part of the clypeus. Pleurites uniformly areolate, each with 2-3 setae on the anterior part. Labrum composed of an intermediate part, which is continuous with the clypeus and bears two medial short tubercles and two lateral bristles, and lateral parts bordered anteriorly by a complete sulcus and posteriorly by a row of bristles. 
AntenNAE. Slender, 3.6 times as long as the head. Intermediate articles up to 2.5 times as long as wide. Article XIV 1.9 times as long as wide, 1.7 times as long as article XIII and only slightly wider than the latter. Setae gradually denser and shorter from basal to distal articles, both ventrally and dorsally. Apical sensilla ca $6 \mu \mathrm{m}$ long, spear-like, without projections, only gently narrowing at about mid-length. Clublike sensilla ca $11 \mu \mathrm{m}$ long, only on article XIV, grouped on the distal parts of both internal and external
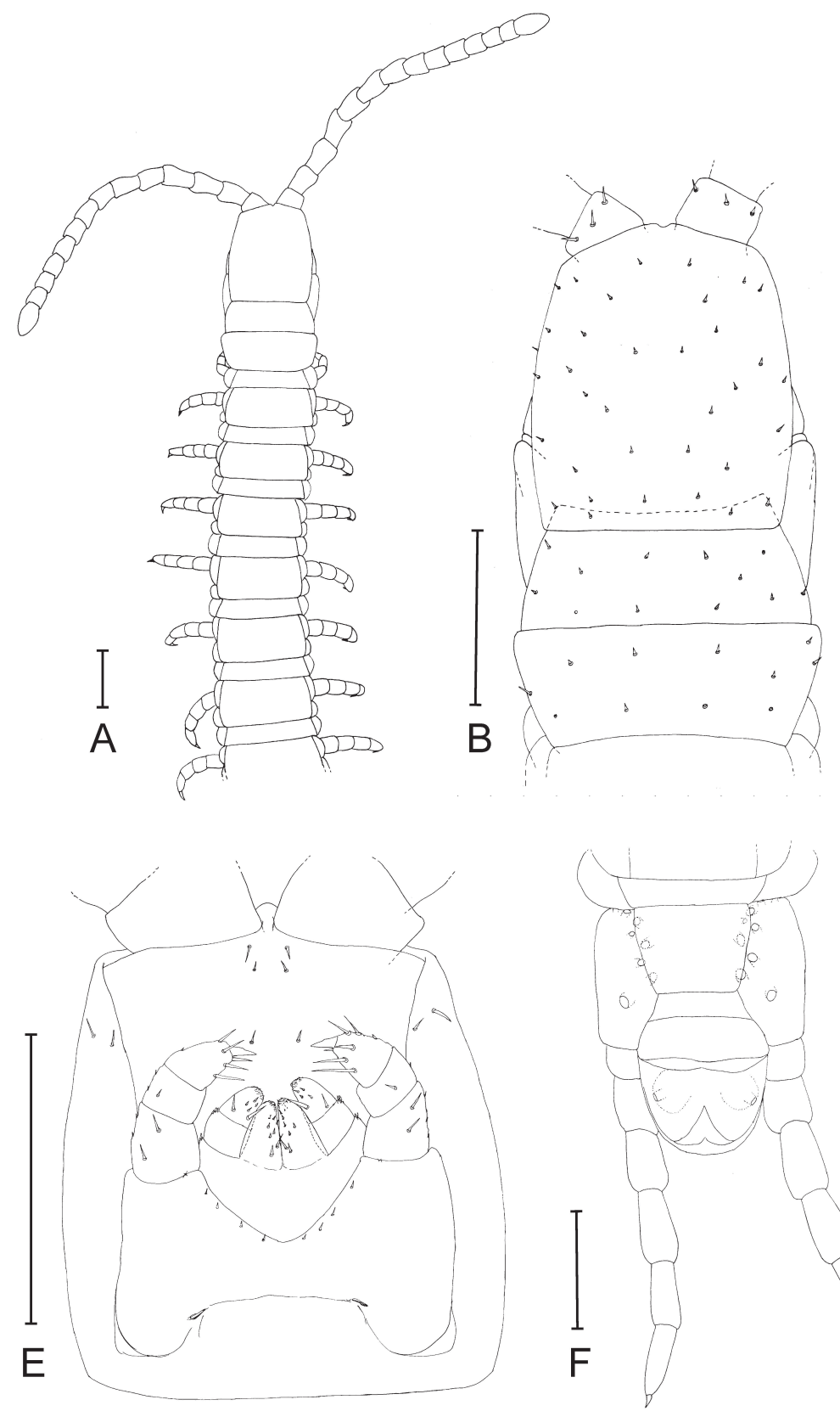

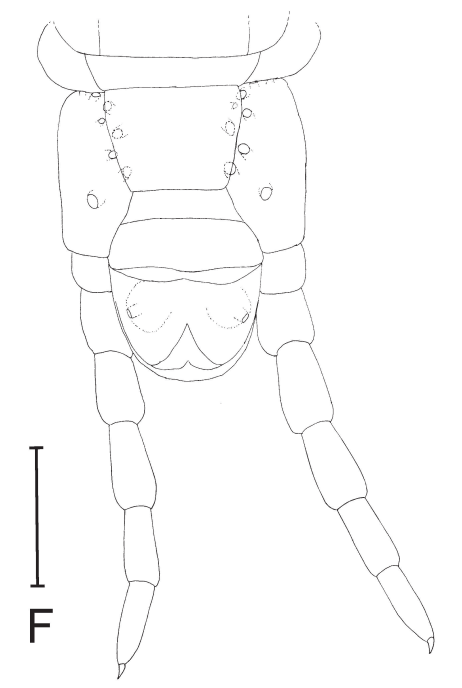

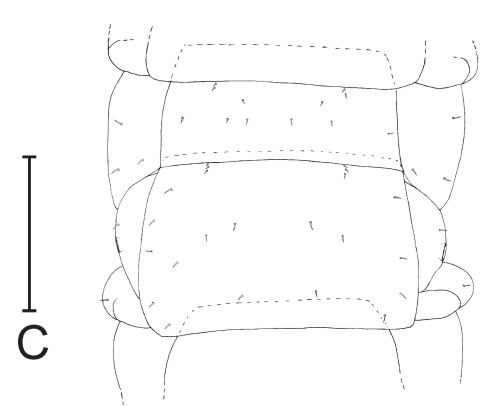
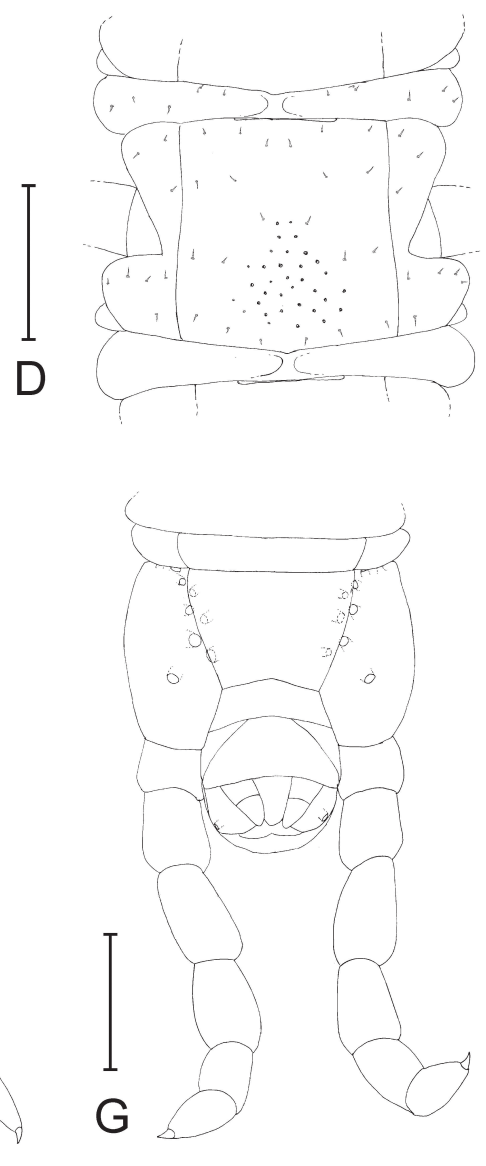

Fig. 1. Endogeophilus ichnusae gen. et sp. nov. A-F. Holotype, $q$. A. Anterior part of the body, dorsal view, setae omitted. B. Head, without antennae, and forcipular segment, dorsal view. C. Leg-bearing segment 21, dorsal view. D. Leg-bearing segment 21, ventral view. E. Head, without antennae, ventral view. F. Ultimate leg-bearing segment and postpedal segments, ventral view, setae omitted. G. Paratype $\mathrm{B}, \hat{O}$, ultimate leg-bearing segment and postpedal segments, ventral view, setae omitted. Line drawings based on photos taken at the microscope. Scale bars $=200 \mu \mathrm{m}$. 
sides. Three longitudinal rows of proprioceptive spine-like sensilla at the bases of articles: ca 3 sensilla in each row on articles II-V, apparently a single sensillum on each side of articles VII-IX and XI-XIII; only a single, dorsal sensillum on articles VI, X and XIV. Groups of 1-3 sensilla, similar to the apical ones, ca $6 \mu \mathrm{m}$ long, on both dorso-external and ventro-internal position, close to the distal margin of articles V, IX and XIII.

MANDIBLES. A single pectinate lamella on each mandible.

FIRST MAXILLAE. Coxosternite entire, without mid-longitudinal sulcus, without setae. Coxal projection sub-triangular, longer than wide, bearing 1-2 basal setae and ca 5-6 more distal spine-like sensilla, the tip covered with fine scales. Telopodite of two articles, the basal one without setae, the distal one with 2 setae and ca 4 spine-like sensilla, the tip covered with fine scales. Coxosternal and telopodital lappets present, very short.

Second maxillae. Coxosternite entire, the intermediate part uniformly sclerotized as the remaining parts; anterior margin widely concave; no sclerotized ridges; setae only close to the anterior margin; metameric pores featuring as transversal slits, close to the postero-medial margin. Telopodite composed

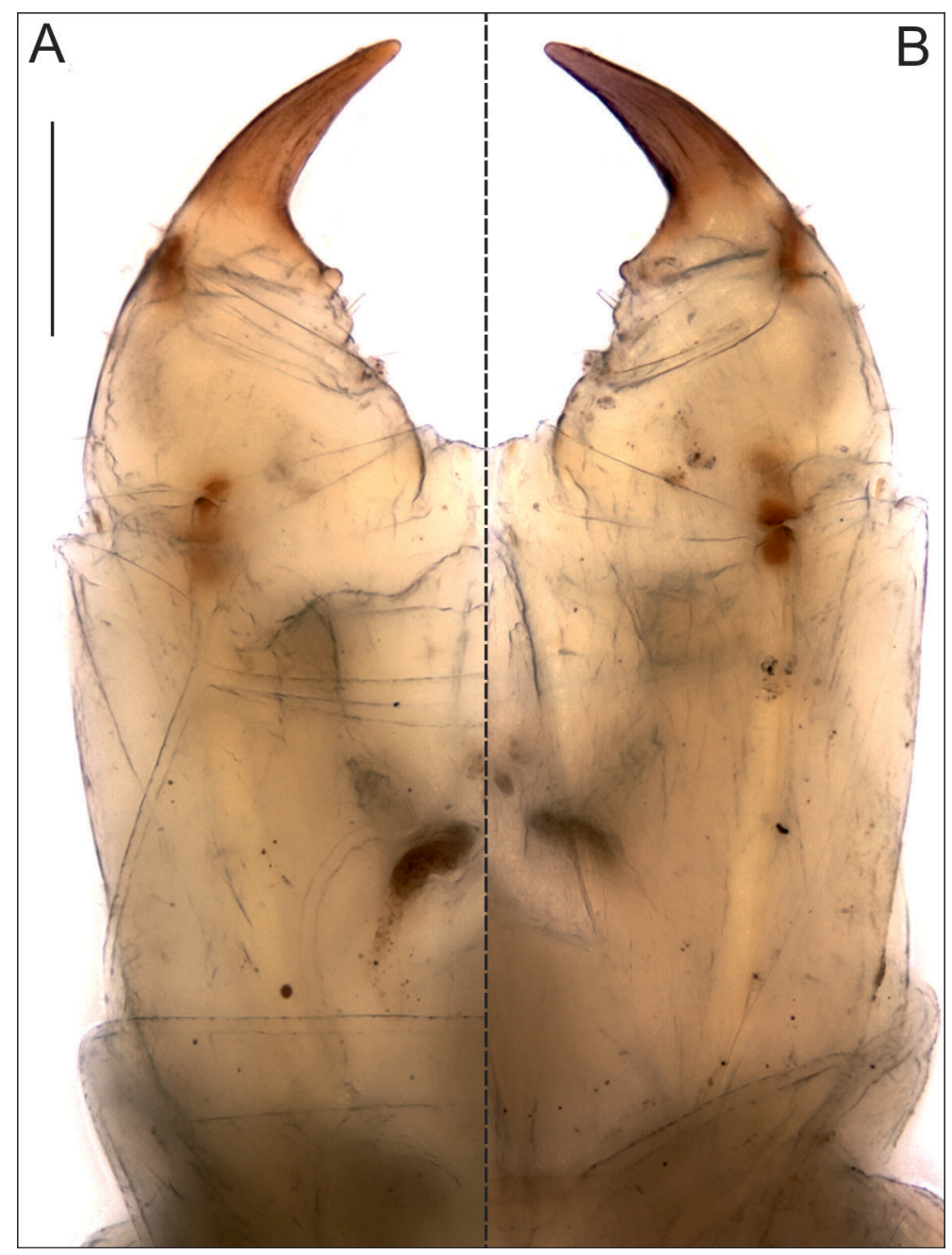

Fig. 2. Endogeophilus ichnusae gen. et sp. nov., holotype,, , forcipular segment, left half. A. Dorsal view. B. Ventral view. Scale bar $=100 \mu \mathrm{m}$. 
of three articles, only slightly narrowing towards the tip; pretarsus in the shape of a simple claw, subconic, only slightly bent, with a small dorsal bulge.

ForCIPULAR SEGMENT. Tergite sub-trapezoid, the lateral margins distinctly converging anteriorly, 1.8 times as wide as long, posteriorly almost as wide as the subsequent metatergite. Pleurites without scapular ridge. Exposed part of the coxosternite 1.2 times as wide as long; anterior margin slightly projecting anteriorly with an intermediate shallow concavity, without denticles; coxopleural sutures complete, entirely ventral, only slightly sinuous, and strongly converging posteriorly; chitin-lines distinct, reaching the condyles, only slightly curved and converging posteriorly. Basal distance between the forcipules 0.1 of the maximum width of the coxosternite. Trochanteroprefemur 1.3 times as wide as long, the internal side much shorter than the external side, without denticles. Forcipular intermediate articles distinct, without denticles, each with a shallow bulge only. Tarsungulum 1.9 times as long as wide, with a basal sub-conic tubercle; distal part almost straight, the internal side with a shallow longitudinal groove between two distinct ridges. Poison calyx sub-spherical, located in the distal part of the trochanteroprefemur.
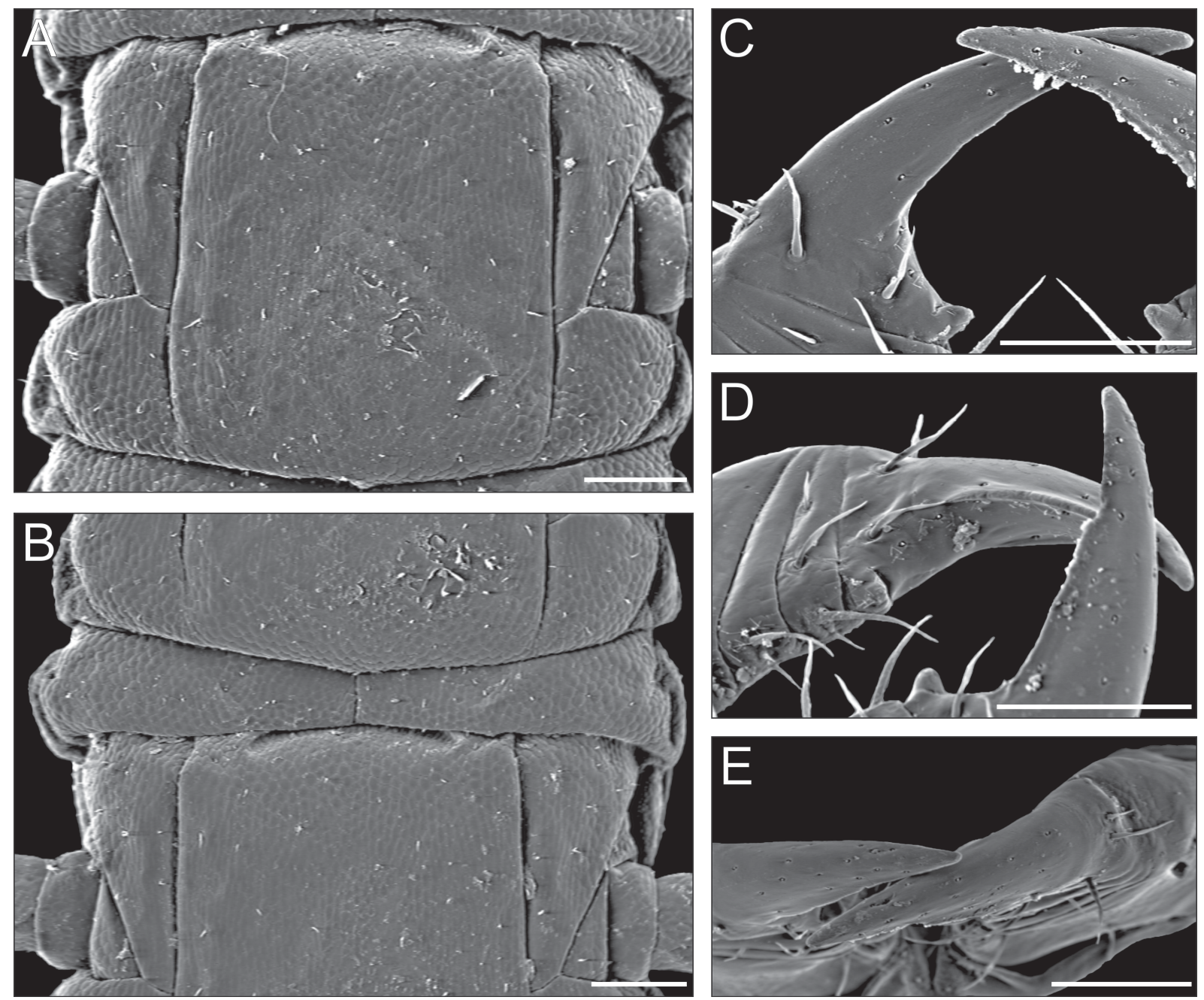

Fig. 3. Endogeophilus ichnusae gen. et sp. nov., paratype A, đ̂. A. Leg-bearing segment 20, ventral view. B. Posterior part of leg-bearing segment 21 and anterior part of segment 22, ventral view. C. Right forcipular tarsungulum, ventral view. D. Right tarsungulum, ventro-mesal view. E. Right tarsungulum, frontal view. SEM micrographs. Scale bars $=50 \mu \mathrm{m}$. 
Leg-Bearing Segments. A total of 107 leg-bearing segments. Metatergite 1 wider than the subsequent one, lateral margins converging posteriorly, without pretergite. No paratergites. Metasternites slightly longer than wide or approximately as long as wide, uniformly areolate, with dense micropores; setae sparse, at most ca $10 \mu \mathrm{m}$ long, approximately arranged into transversal rows; metasternites of some anterior segments with a very shallow, bilobate socket on the anterior margin, 0.6 times as wide as the margin of metasternite, resembling a "carpophagus" pit, but no corresponding medial peg on the posterior margin. Glandular pores on the metasternites from 2 to penultimate, up to 20-25 pores on each metasternite, loosely arranged in a sub-ovoid/sub-triangular pore-field on the posterior half of each metasternite; each pore with a sub-circular lumen with a diameter of 1.1-1.3 $\mu \mathrm{m}$, surrounded by a distinct ring-like uninterrupted ridge. Procoxa distinctly longer than metacoxa, both sclerites without glandular pores. Leg claws simple, uniformly bent; a pair of accessory spines, reaching approximately the mid-length of the pretarsus, the anterior spine slightly longer than the posterior one.

UltimATE LEG-BEARING SEgMENT. Pleuropretergite entire, lacking sutures or sulci or notches, 3.4 times as wide as long. Metatergite sub-trapezoid, 1.3 times as wide as long, lateral margins convex and distinctly converging posteriorly, posterior margin slightly convex. Presternite 5.0 times as wide as long, not medially constricted. Metasternite sub-trapezoid, 1.2 times as wide as long, anteriorly 1.4 times as wide as posteriorly, lateral margins anteriorly slightly convex, posteriorly almost straight and converging backwards, posterior margin slightly concave; setae uniformly sparse. Coxopleuron 2.0 times as long as

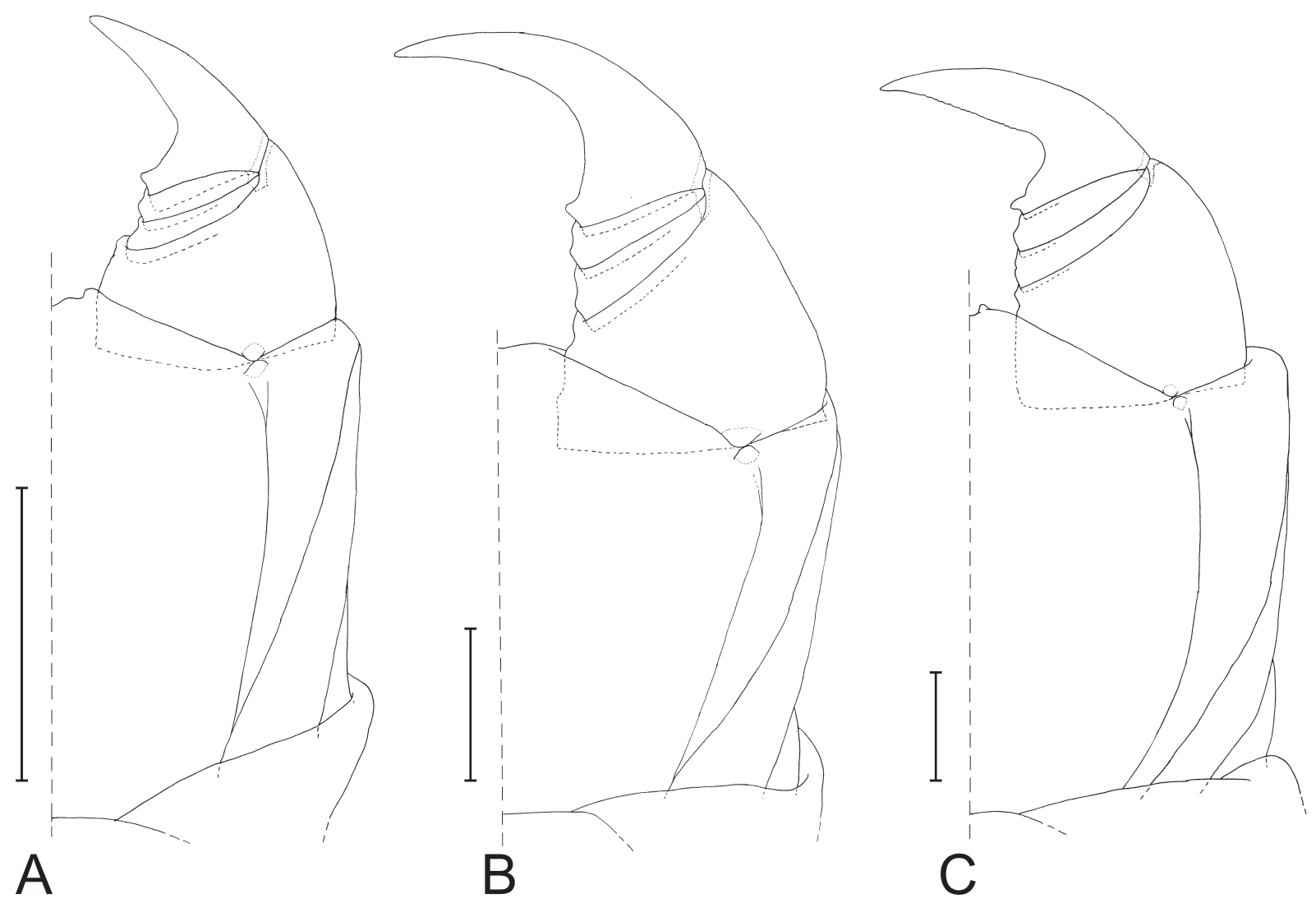

Fig. 4. Forcipules of Endogeophilus ichnusae gen. et sp. nov. and the two most similar geophilid species. Left part of the forcipular segment, ventral view, in adult females. A. E. ichnusae gen. et sp. nov., holotype, , , original drawing. B. Geophilus electricus (Linnaeus, 1758), original drawing from a representative specimen, + (see 'Material and methods'). C. Galliophilus beatensis Ribaut \& Brolemann, 1927, holotype,, , redrawn from Brolemann (1927). Scale bars $=200 \mu \mathrm{m}$. 
wide, 1.5 times as long as the metasternite; setae uniformly sparse. Coxal organs of each coxopleuron opening through 13-14 independent pores, which are approximately aligned from the dorsal to the ventral surface through the anterior side of the coxopleuron: most pores covered by pleuropretergite, metatergite and presternite; 2 pores exposed on the dorso-lateral side; 6-7 partially exposed on the ventral side, close to the metasternite; a single pore isolated on the postero-central part of the ventral side. Telopodite 7.6 times as long as wide, 2.0 times as long and 1.4 times as wide as the penultimate telopodite; 6 articles, all covered dorsally with sparse longer setae, ventrally with dense shorter setae. Pretarsus in the shape of a pointed claw, similar but only half the length of the penultimate.

Postpedal SEgments. Genital pleurosternite entire. Gonopods in the shape of a short slightly bilobate lamina. Anal organs relatively large, anal pores exposed.

\section{Male}

Description of the terminal part of the body of the paratype B (see also Fig. 1G). Same as the holotype, except for the following characters.

Ultimate Leg-Bearing Segment. Coxopleuron 1.8 times as long as wide; setae distinctly denser close to the postero-mesal margin. Coxal organs of each coxopleuron opening through 14-15 independent pores. Telopodite 7.0 times as long as wide, 2.0 times as long and 1.7 as wide as the penultimate.

Postpedal segments. Complete sutures between the genital sternite and the pleurites. Gonopods biarticulated, well separated, with a sub-conic penis in between.

\section{Distribution and habitat}

Endogeophilus ichnusae gen. et sp. nov. has been found only in two localities, about $25 \mathrm{~km}$ from each other, in the Sulcis-Iglesiente area, SW Sardinia, at 280-610 m above sea level (Fig. 5). The type locality (Colle di Campanasissa) has a granitic substrate covered with maquis consisting of Pistacia spp. (L. Fancello, pers. com.), whereas the other locality (Mamenga) has a calcareous substrate covered with Quercus ilex L. wood (Bardiani 2011).

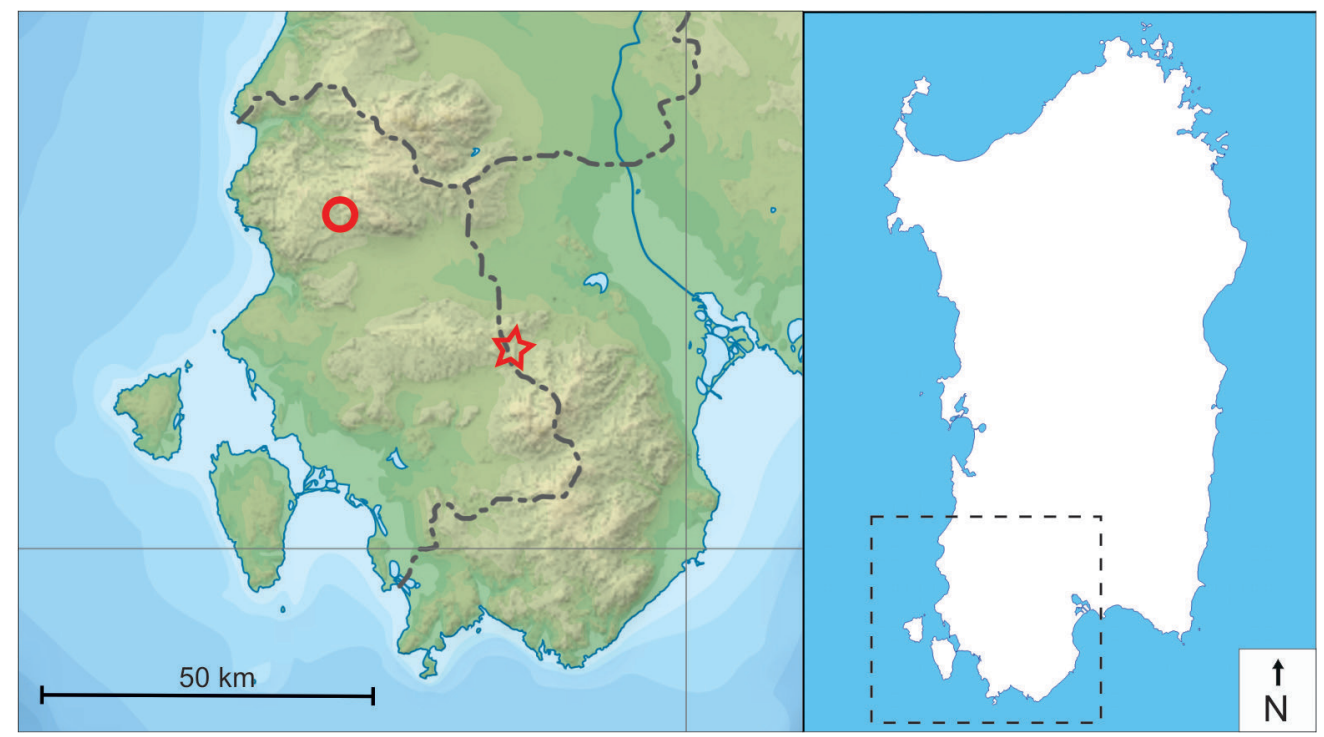

Fig. 5. Localities where Endogeophilus ichnusae gen. et sp. nov. has been collected, in the SulcisIglesiente, Sardinia. The type locality is indicated by a star. 


\section{Discussion}

\section{Phyletic position and classification}

The new centipede species obviously belongs to the family Geophilidae sensu stricto, as traditionally circumscribed (Bonato 2011). This is suggested by the combination of major features of the labrum (a narrow intermediate part with tubercles and two wider lateral parts with bristles), the mandibles (bearing a single, pectinate lamella), the second maxillae (with sub-conic claws without filaments) and the gonopods (an undivided lamina in the female). However, a sound phylogenetic analysis to elucidate the position of the new species within Geophilidae is unfeasible for the time being, because only incomplete and sometimes unreliable information are available on the morphology of many geophilid genera. Nevertheless, the new species fits within a subgroup of geophilids that has been variously distinguished as a subfamily Geophilinae (Attems 1926, 1929) or tribe Geophilini (Brolemann 1930) or subtribe Geophilina (Brölemann 1909). This subgroup, possibly non monophyletic, differs from the remaining Geophilidae in the combination of the following characters: head as long as wide or only slightly longer than wide, second maxillary coxosternite with a continuous broad connection between the two halves and without paired sclerotized ridges (either statuminia or circumforaminal rings; see Bonato et al. 2011), forcipular tergite as wide as the subsequent metatergite or only slightly narrower than it, and forcipules not reaching the anterior margin of the head.

Considering all known genera in this subgroup of geophilids (Table 1), the new species differs from them in one or more characters that are traditionally given taxonomic value at the genus rank, above all in the forcipular coxosternite (features of coxopleural sutures, chitin-lines, denticles), trunk metasternites (presence of carpophagus pit and pattern of pore-fields), and ultimate leg-bearing segment (shape of the metasternite, arrangement of coxal pores and form of the pretarsi). As a consequence, following current practice in geophilid taxonomy, the new species is classified here in a distinct genus.

Endogeophilus ichnusae gen. et sp. nov. shares most traits with Geophilus electricus (Linnaeus, 1758), which is the type species of Geophilus Leach, 1814 (a large, heterogeneous genus including ca 140 species inhabiting the entire Holarctic region; see Bonato 2011), and Galliophilus beatensis Ribaut \& Brolemann, 1927, which is the only species in the genus Galliophilus Ribaut \& Brolemann, 1927 (recorded only once in the Pyrenees, with two additional records from the central Iberian peninsula: Brolemann 1927; García Ruiz \& Serra 2000) (Table 2; Fig. 4). In particular, E. ichnusae gen. et sp. nov. resembles G. electricus in the forcipular coxosternite and the ultimate leg-bearing segment, especially in the arrangement of the coxal pores, which is otherwise uncommon in geophilids (Table 1). However, E. ichnusae gen. et sp. nov. differs from G. electricus, and from all the other species of Geophilus, in other characters including the shape of the forcipular tarsungula (distinctly longer and more curved in all Geophilus species), the shape of the sternal pore-fields (never medially elongated in a sub-triangular area in Geophilus) and the number of legs (up to 89 pairs recorded in Geophilus species, but usually much less). Additionally, E. ichnusae gen. et sp. nov. differs from most species of Geophilus other than G. electricus also in the chitin-lines (incomplete in most Geophilus species) and the arrangement of coxal pores (all in ventral position in most Geophilus species). On the other hand, E. ichnusae resembles Galliophilus beatensis in other features that are infrequent or even unknown in other geophilids, i.e., the stout forcipular tarsungula (Fig. 4) and the elongated trunk segments. However, while broad pore-fields are easily detected in all three specimens of E. ichnusae, the holotype of G. beatensis was described and illustrated as lacking recognisable sternal pore-areas: even after adequate preparation for microscopic examination of the cuticle of a representative anterior metasternite, only rare pores were observed, along the margins of the metasternites, with at most two paired posterior small clusters (Brolemann 1927, 1930). Further, at difference with E. ichnusae gen. et sp. nov., the coxal pores of the holotype of $G$. beatensis were described and illustrated as sparse on the whole ventral and lateral sides of the 
Table 2. Differences between Endogeophilus ichnusae gen. et sp. nov. and the most similar known species of Geophilidae. Information for Galliophilus beatensis Ribaut \& Brolemann, 1927 is from Brolemann $(1927,1930) . *=$ García Ruiz \& Serra (2000) reported the following values for two specimens from the central Iberian Peninsula referred to Galliophilus beatensis: 76 (sic) in a $\widehat{O}, 73$ in a ${ }_{+}$.

\begin{tabular}{|c|c|c|c|}
\hline Character & $\begin{array}{c}\text { Endogeophilus ichnusae } \\
\text { sp. nov. }\end{array}$ & $\begin{array}{l}\text { Geophilus electricus } \\
\text { (Linnaeus, 1758) }\end{array}$ & $\begin{array}{c}\text { Galliophilus beatensis } \\
\text { Ribaut \& Brolemann, } 1927\end{array}$ \\
\hline antennal articles & elongate & short & short \\
\hline forcipular tarsungulum & $\begin{array}{l}\text { narrow, internal margin } \\
\text { moderately angulate }\end{array}$ & $\begin{array}{l}\text { long, internal margin non } \\
\text { angulate }\end{array}$ & $\begin{array}{l}\text { wide, internal margin } \\
\text { distinctly angulate }\end{array}$ \\
\hline sternal pore-fields & $\begin{array}{l}\text { distinct, longitudinally } \\
\text { elongate }\end{array}$ & distinct, transversally broad & no (only rare pores) \\
\hline number of leg pairs & of 91-95(n=2), ㅇ $107(\mathrm{n}=1)$ & $55-75(\mathrm{n}=$ many $)$ & q $85(\mathrm{n}=1)^{*}$ \\
\hline maximum body length & $34 \mathrm{~mm}$ & $45 \mathrm{~mm}$ & $51 \mathrm{~mm}$ \\
\hline arrangement of coxal pores & $\begin{array}{c}\text { mainly along metatergite and } \\
\text { metasternite, plus } 1 \text { isolated } \\
\text { ventral }\end{array}$ & $\begin{array}{c}\text { mainly along metatergite and } \\
\text { metasternite, plus } 1 \text { isolated } \\
\text { ventral }\end{array}$ & $\begin{array}{l}\text { scattered, on ventral and } \\
\text { lateral surface }\end{array}$ \\
\hline pretarsus of ultimate leg & present (both sexes) & present (both sexes) & absent (at least in female) \\
\hline
\end{tabular}

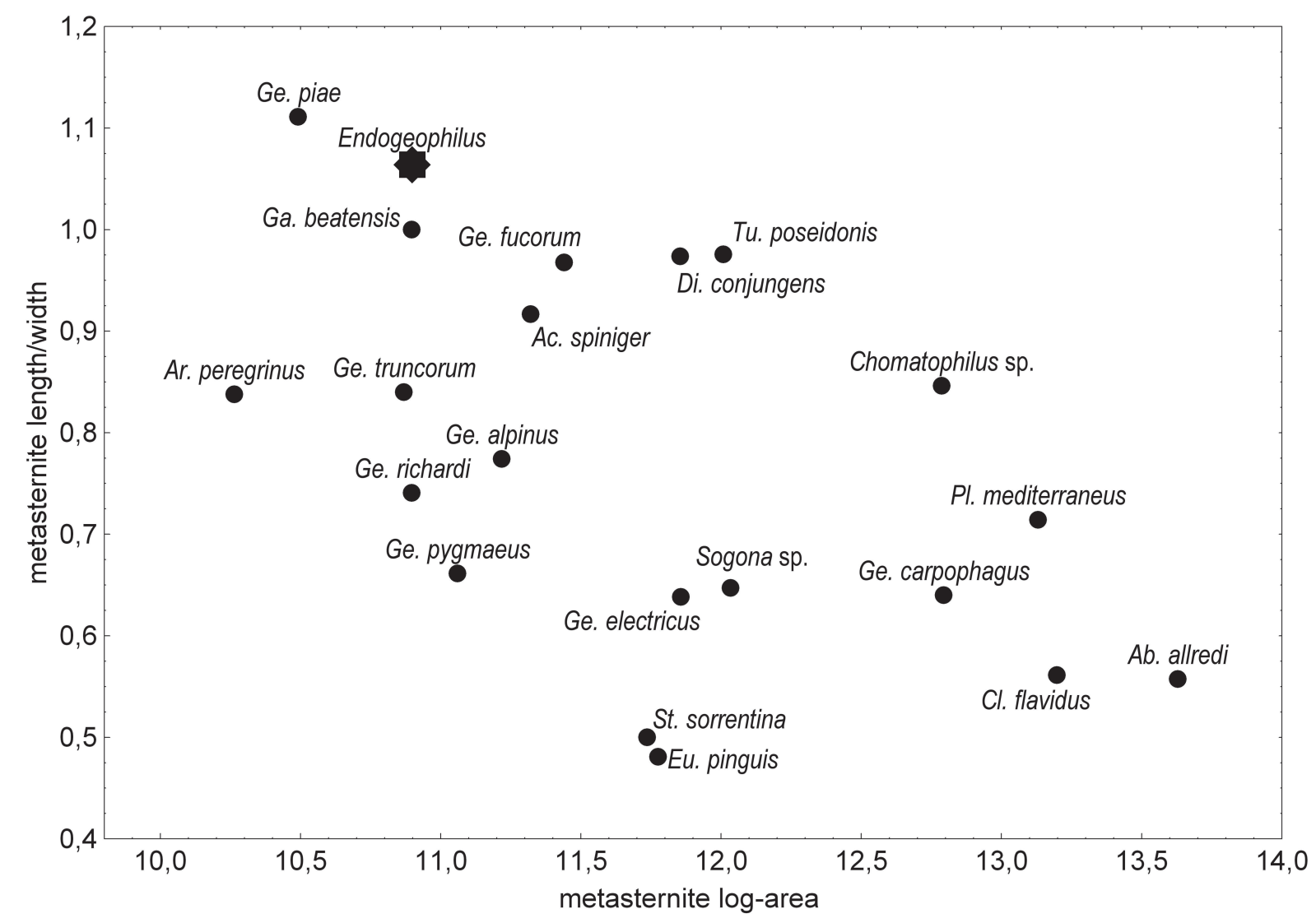

Fig. 6. Variation in the elongation of a single leg-bearing segment in a sample of species of Geophilidae, including Endogeophilus ichnusae gen. et sp. nov. The length/width ratio was measured on a metasternite at about $20 \%$ of the longitudinal series of leg-bearing segments, and the area of the metasternite (length $\times$ width, both in $\mu \mathrm{m}$, log-transformed) has been taken as a proxy for body size. Full names of species in 'Material and methods'. 
coxopleura, only slightly denser close to the metasternite, without dorsal pores and without a distinctly isolated posterior pore (Brolemann 1927, 1930).

\section{Derived morphological features: adaptation to a more strictly endogeic habit?}

All three specimens of E. ichnusae gen. et sp. nov. have well-developed gonopods, so that their length (31-34 mm) can be taken as a good estimate of the average size of the species at full growth. Thus, the body size of E. ichnusae gen. et sp. nov. is well within the range recorded in the other geophilids: most species are $1-5 \mathrm{~cm}$ long, whereas significantly higher values (up to ca $10 \mathrm{~cm}$ ) have been recorded only in rare species of Chomatophilus Pocock, 1896, Gnathoribautia Brölemann, 1909, Maoriella Attems, 1903 and Pleurogeophilus Verhoeff, 1901 (Bonato 2011).

However, E. ichnusae gen. et sp. nov. departs from most other geophilids in some major structural features: supernumerary and elongated trunk segments, stout legs and body covered with sparse, short setae.

TRUnK SEgmentation. The number of leg-bearing segments in E. ichnusae gen. et sp. nov. (91-107) is remarkable in comparison to most other geophilids. Among the ca 560 known species in the Geophilidae sensu stricto (Bonato 2011), the overall range is 29-125 segments, however figures higher than 90 segments have been recorded in a few species only: Chomatophilus smithi Pocock, 1896 (up to 115 segments; Crabill 1968), Maoriella aucklandica Attems, 1903 (up to 91 segments; Attems 1903),

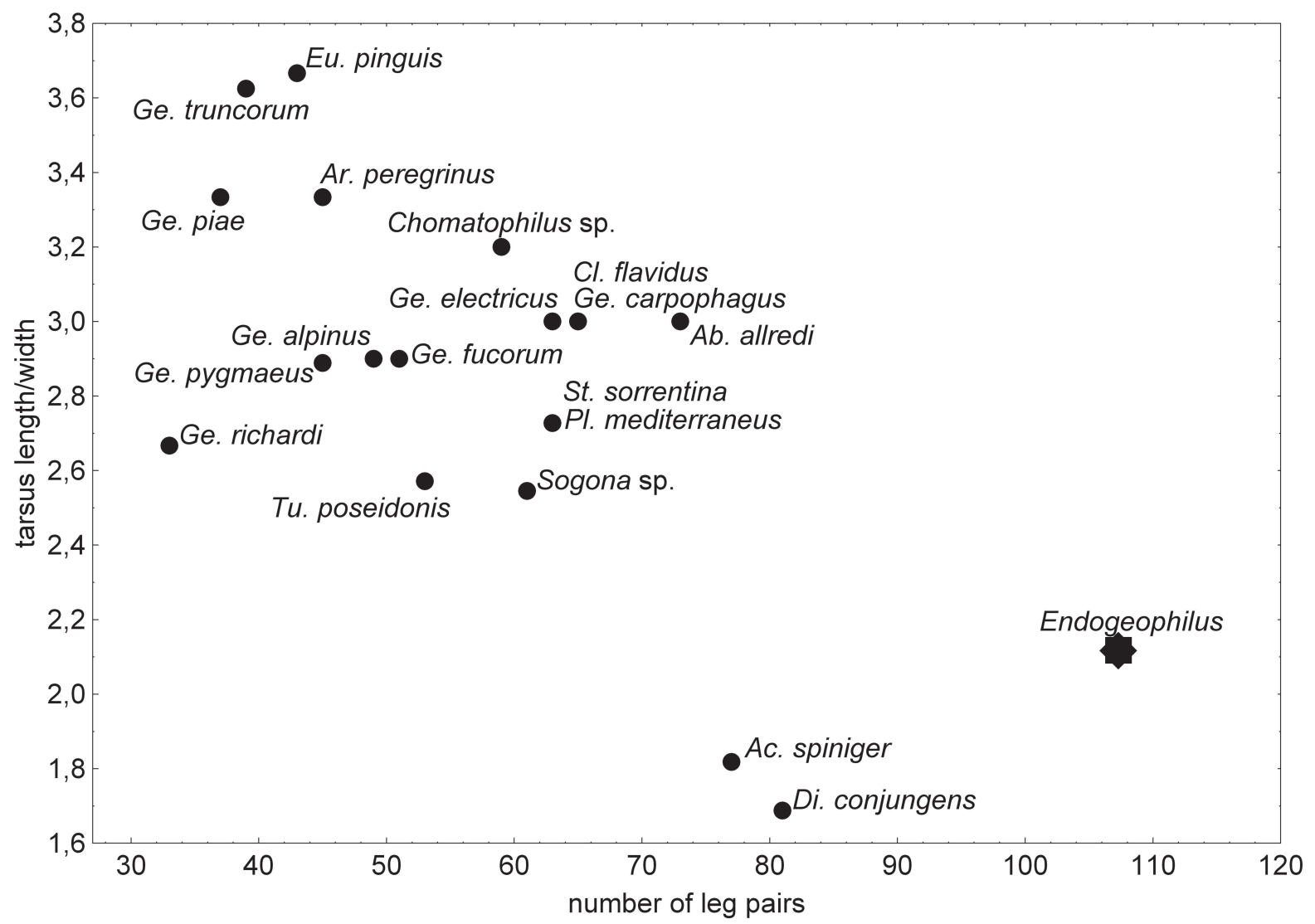

Fig. 7. Variation in the elongation of legs and the number of legs in a sample of species of Geophilidae, including Endogeophilus ichnusae gen. et sp. nov. The length/width ratio of a leg tarsus was measured at about $20 \%$ of the longitudinal series of legs. Full names of species in 'Material and methods'. 
Ribautia taeniata Ribaut, 1923 (up to 125 segments; Ribaut 1923), Stenotaenia sturanyi (Attems, 1903) (up to 115 segments; Bonato \& Minelli 2008), Tampiya pylorus Chamberlin, 1912 (125 segments in the single specimen known; Chamberlin 1912), and Telocricus multipes Chamberlin, 1915 (113 segments in the single specimen known; Chamberlin 1915).

ELONGATION OF TRUNK SEGMENTS. E. ichnusae gen. et sp. nov. departs from most other geophilids also in the relative elongation of the single leg-bearing segments. By comparing the anterior part of the trunk in a sample of geophilids (Fig. 6), the metasternites are wider than long in the majority of the species, whereas they are longer than wide in E. ichnusae gen. et sp. nov. and at least in another species, namely Geophilus piae Minelli, 1983. The latter is similar to E. ichnusae gen. et sp. nov. in body width but remarkably different in body length: G. piae has less than 40 pairs of legs and does not surpass $10 \mathrm{~mm}$ in total length (Minelli 1983).

ELONGATION OF LEGS. When comparing geophilids with regard to the elongation of the legs (Fig. 7), E. ichnusae gen. et sp. nov. belongs to a minor group of species with relatively stout legs, contrasting with a majority of species with more elongate legs. Besides Endogeophilus gen. nov., quite stout legs are present also in Acanthogeophilus Minelli, 1982 and Diphyonyx Bonato, Zapparoli \& Minelli, 2008.

Coverage Of Setae. The longest setae on the cephalic plate of E. ichnusae gen. et sp. nov. (ca $15 \mu \mathrm{m}$ long) are distinctly shorter than those measured in most other species of a sample of geophilids $(50-120 \mu \mathrm{m})$

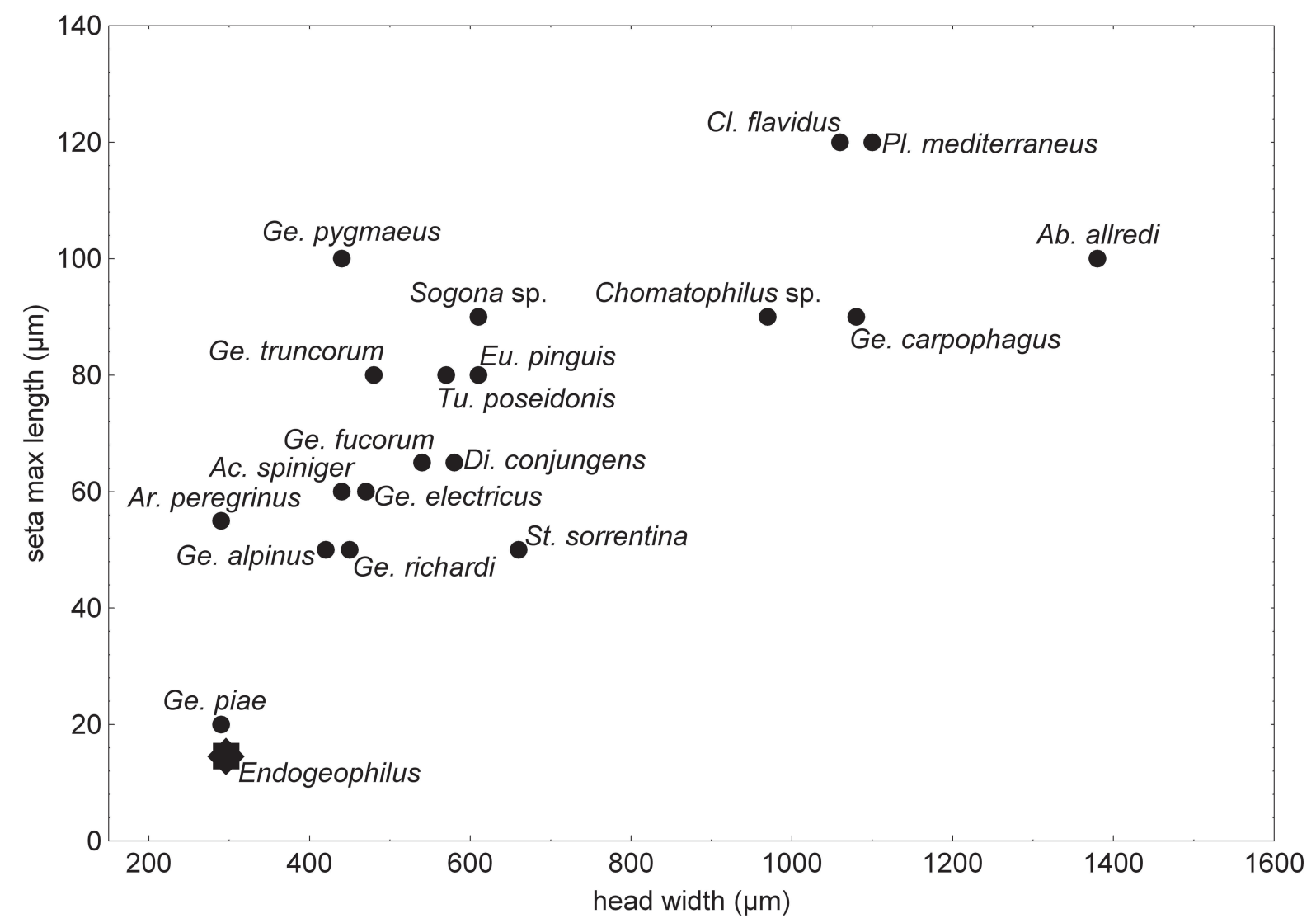

Fig. 8. Variation in the length of setae in a sample of species of Geophilidae, including Endogeophilus ichnusae gen. et sp. nov. The longest seta on the cephalic plate was measured, and the maximum width of the cephalic plate has been taken as a proxy for body size. Full names of species in 'Material and methods'. 
(Fig. 8). Comparably short setae (not surpassing $20 \mu \mathrm{m}$ ) are also found in Geophilus piae, which is similar to E. ichnusae gen. et sp. nov. in body width but remarkably different in body length (see above).

Geophilomorph centipedes spend most of their life in the soil, inclusive of leaf litter, even though some species show up on the surface either occasionally or regularly (pers. obs.). Blindness and lack of pigmentation are common to the entire clade and are usually regarded as adaptations to a predominantly endogeic lifestyle. The unusual habitus of Endogeophilus gen. nov. (very slender shape, supernumerary longitudinal articulations, stout legs and short sparse setae) is suggestive of further specialization to living in the micro-crevices of fine-grain soils. A somehow similar habitus distinguishes strictly endogeic lineages in distantly related arthropod groups. In particular, among the staphylinid beetles, the endogeic Leptotyphlinae are remarkably elongate and short-legged, however much smaller in length (less than $2 \mathrm{~mm}$; Coiffait 1959) than Endogeophilus gen. nov. A parallel morphological syndrome is recurrent also in the aquatic interstitial fauna, e.g., in isopods (Microparasellidae, Microcerberidae), in the harpacticoid copepods, and even in ciliated protozoans (Delamare Deboutteville 1960). That E. ichnusae gen. et sp. nov. may have a more strictly endogeic lifestyle than other geophilids is suggested also by the fact that it has been discovered only recently, when specific sampling techniques for deep-soil fauna has been employed, while it has escaped detection in all previous surveys, which usually employed manual sampling on litter and high soil strata (see Zapparoli 2011 for further comments), or were instead specific for caves (e.g., Zapparoli 2009). No other specimens of E. ichnusae gen. et sp. nov. were found by one of us (L.B.) when sampling geophilomorphs in the same part of Sardinia (Sulcis-Iglesiente), however with conventional methods and thus focussing on the higher soil levels.

\section{Acknowledgments}

We are grateful to Luca Fancello (Cagliari, Italy) for allowing us to study the centipedes he collected in Sardinia and for information on the sampled sites, Douglas Yanega (University of California, Riverside) and Fabio G. Cupul-Magaña (University of Guadalajara, México) for loan of specimens, and Achille Casale (formerly, University of Sassari, Italy) for suggestions on the soil fauna. The research has been supported by the Italian Ministry of the University and Scientific Research MIUR (PRIN 20085YJMTC).

\section{References}

AA.VV. 1983. Il popolamento animale e vegetale della Sardegna. Lavori della Società Italiana di Biogeografia, N.S. 8 (1980): 1-874.

Attems C.G. 1903. Synopsis der Geophiliden. Zoologische Jahrbücher, Abteilung für Systematik 18: $155-302$.

Attems C.G. 1926. Fünfter Unterstamm der Arthropoda. Chilopoda. In: Kükenthal W. \& Krumbach Th. (eds) Handbuch der Zoologie 4 (1): 239-402. De Gruyter, Berlin and Leipzig.

Attems C.G. 1929. Myriapoda. 1. Geophilomorpha. Das Tierreich 52. De Gruyter, Berlin.

Bardiani M. 2011. Introduction. In: Nardi G., Whitmore D., Bardiani M., Birtele D., Mason F., Spada L. \& Cerretti P. (eds) Biodiversity of Marganai and Montimannu (Sardinia). Research in the framework of the ICP Forests network: 15-56. Conservazione Habitat Invertebrati 5, Cierre Edizioni, Sommacampagna, Verona.

Bonato L. 2011. Chilopoda - Taxonomic overview. Order Geophilomorpha. In: Minelli A. (ed.), Treatise on Zoology - Anatomy, Taxonomy, Biology. The Myriapoda. Volume 1: 407-443. Brill, Leiden.

Bonato L. \& Minelli A. 2008. Stenotaenia C.L. Koch, 1847, a hitherto unrecognized lineage of Western Palaearctic centipedes with unusual diversity in body size and segment number (Chilopoda: 
Geophilidae). Zoological Journal of the Linnean Society 153: 253-286. http://dx.doi.org/10.1111/ j.1096-3642.2008.00394.x

Bonato L., Barber A. \& Minelli A. 2006. The European centipedes hitherto referred to Eurygeophilus, Mesogeophilus and Chalandea (Chilopoda, Geophilomorpha): taxonomy, distribution and geographic variation of the segment number. Journal of Natural History 40: 415-438. http://dx.doi. org/10.1080/00222930600661839

Bonato L., Chagas Junior A., Edgecombe G.D., Lewis J.G.E., Minelli A., Pereira L.A., Shelley R.M., Stoev P. \& Zapparoli M. 2016. ChiloBase 2.0 -A World Catalogue of Centipedes (Chilopoda). Available from http://chilobase.biologia.unipd.it [accessed 9 Feb. 2016]

Bonato L., Edgecombe G.D., Lewis J.G.E., Minelli A., Pereira L.A., Shelley R.M. \& Zapparoli M. 2010. A common terminology for the external anatomy of centipedes (Chilopoda). Zookeys 69: 17-51. http:// dx.doi.org/10.3897/zookeys.69.737

Bonato L., Iorio E. \& Minelli A. 2011. The centipede genus Clinopodes C.L. Koch, 1847 (Chilopoda: Geophilidae): a reassessment of species diversity and distribution, with a new species from the Maritime Alps. Zoosystema 33: 175-205. http://dx.doi.org/10.5252/z2011n2a3

Brölemann H.W. 1909. À propos d'un système des géophilomorphes. Archives de Zoologie Expérimentale et Générale (5) 3: 303-340.

Brolemann H.W. 1927. Trois myriapodes français nouveaux. Bulletin de la Société d'Histoire Naturelle de Toulouse 56: 101-110.

Brolemann H.W. 1930. Éléments d'une Faune des Myriapodes de France. Chilopodes. Imprimérie Toulousaine, Toulouse.

Cerretti P., Mason F., Minelli A., Nardi G. \& Whitmore D. (eds) 2009. Research on the Terrestrial Arthropods of Sardinia. Zootaxa 2318: 1-602.

Chamberlin R.V. 1912. The Chilopoda of California. III. Pomona College Journal of Entomology 4: 651-672.

Chamberlin R.V. 1915. New chilopods from Mexico and the West Indies. Bulletin of the Museum of Comparative Zoology, Harvard College 59: 493-541. Available from http://biodiversitylibrary.org/ page/6340205 [accessed 29 Aug. 2016]

Coiffait H. 1959. Monographie des Leptotyphlites (Col. Staphylinidae). Revue Française d'Entomologie 26: $237-437$.

Crabill R.E. 1954. A conspectus of the northeastern North American species of Geophilus (Chilopoda Geophilomorpha Geophilidae). Proceedings of the Entomological Society of Washington 56: 172-188.

Crabill R.E. 1961. Concerning the identities of Nannocrix and Sogona, with pertinent morphological notes. Proceeding of Entomological Society of Washington 63: 125-135.

Crabill R.E. 1968. On the true identity of Chomatophilus with description of a new species, and with key and catalogue of all sogonid genera (Chilopoda: Geophilomorpha: Sogonidae). Proceedings of the Entomological Society of Washington 70: 323-331. Available from http://biodiversitylibrary.org/ page/16262340 [accessed 30 Aug. 2016]

Crabill R.E. 1969. Review of Arenophilus and key to all species. Entomological News 80: 7-11.

Delamare Deboutteville C. 1960. Biologie des eaux souterraines littorales et continentales. Vie et Milieu Suppl. 9: 1-740. 
Fancello L., Hernando C. \& Leo P. 2009. The endogean beetle fauna of the Marganai-Oridda-Valle del Leni area (SW Sardinia), with description of seven new species of Staphylinidae Leptotyphlinae (Coleoptera). In: Cerretti P., Mason F., Minelli A., Nardi G. \& Whitmore D. (eds) Research on the Terrestrial Arthropods of Sardinia (Italy). Zootaxa 2318: 317-338.

García Ruiz A. \& Serra A. 2000. Nuevas citas de quilópodos (Myriapoda, Chilopoda) para la fauna de la Península Ibérica. Boletin de la Asociation Española de Entomologia 24: 187-191.

Hadley A. 2008. Combine ZP. Available from http://combinezp.software.informer.com/ [accessed 30 Aug. 2016]

Jones R.E. 1998. On the species of Tuoba (Chilopoda: Geophilomorpha) in Australia, New Zealand, New Caledonia, Solomon Islands and New Britain. Records of the Western Australian Museum 18: 333-346. Western Australian Museum, Perth.

Minelli A. 1983. On Sardinian centipedes (Chilopoda). Bollettino di Zoologia 49 (1982): 1-16. http:// dx.doi.org/10.1080/11250008209439365

Nardi G., Whitmore D., Bardiani M., Birtele D., Mason F., Spada L. \& Cerretti P. (eds) 2011. Biodiversity of Marganai and Montimannu (Sardinia). Research in the framework of the ICP Forests network. Conservazione Habitat Invertebrati 5. Cierre Edizioni, Sommacampagna, Verona.

Pace R. 1996. Coleoptera Staphylinidae Leptotyphlinae. Fauna d'Italia XXXIV, Calderini, Bologna.

Pereira L.A. 2000. The preparation of centipedes for microscopical examination with particular reference to the Geophilomorpha. Bulletin of the British Myriapod Group 16: 22-25.

Ribaut H. 1923. Chilopodes de la Nouvelle-Calédonie et des îles Loyalty. In: Sarasin F. \& Roux J. (eds) Nova Caledonia, Recherches Scientifiques en Nouvelle-Calédonie et aux Îles Loyalty 3 (1): 1-79. C.W. Kreidel's Verlag, Berlin and Wiesbaden.

Zapparoli M. 2009. An annotated catalogue of the epigeic and cave centipedes (Chilopoda) of Sardinia. In: Cerretti P., Mason F., Minelli A., Nardi G. \& Whitmore D. (eds) Research on the Terrestrial Arthropods of Sardinia (Italy). Zootaxa 2318: 56-168.

Zapparoli M. 2011. New records and remarks on the centipede fauna of endogeic habitats of Sardinia (Chilopoda). In: Nardi G., Whitmore D., Bardiani M., Birtele D., Mason F., Spada L. \& Cerretti P. (eds) Biodiversity of Marganai and Montimannu (Sardinia). Research in the framework of the ICP Forests network: 223-242. Conservazione Habitat Invertebrati 5, Cierre Edizioni, Sommacampagna, Verona.

Manuscript received: 1 March 2016

Manuscript accepted: 28 April 2016

Published on: 21 September 2016

Topic editor: Rudy Jocqué

Desk editor: Kristiaan Hoedemakers

Printed versions of all papers are also deposited in the libraries of the institutes that are members of the EJT consortium: Muséum national d'Histoire naturelle, Paris, France; Botanic Garden Meise, Belgium; Royal Museum for Central Africa, Tervuren, Belgium; Natural History Museum, London, United Kingdom; Royal Belgian Institute of Natural Sciences, Brussels, Belgium; Natural History Museum of Denmark, Copenhagen, Denmark; Naturalis Biodiversity Center, Leiden, the Netherlands. 